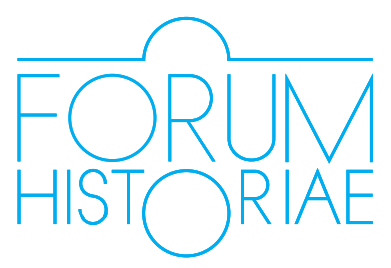

\title{
Sealed Borders, Trafficking and Deportation - Austrian Refugees in the Czechoslovak Border Region after the "Anschluss"
}

\author{
Wolfgang Schellenbacher
}

\begin{abstract}
:
SCHELLENBACHER, Wolfgang: Sealed Borders, Trafficking and Deportation - Austrian Refugees in the Czechoslovak Border Region after the "Anschluss".

Between the "Anschluss" of Austria to Nazi Germany in March 1938 and the first mass transports from Vienna in 1941, 135,000 Austrians, who were defined as Jewish by the Nuremburg laws, fled abroad. This article looks at the key moments in their expulsion, focusing on those who sought refuge in Czechoslovakia, especially in the border regions during 1938 and an examination of the processes of flight, trafficking, smuggling and illegal expulsions as the geo-political landscape of both countries changed dramatically. Using biographies reconstructed through transnational research and the application of geo-refencing, fresh insight into the major routes taken and the effect on the fates of those who fled or were expelled to Czechoslovakia is offered. Keywords: Austria, Czechoslovakia, Holocaust, Jews, Refugees, Border Region, Transnational Biographies, Anschluss
\end{abstract}

DOI: https://doi.org/10.31577/forhist.2019.13.1.6

\section{Introduction}

"O n April 16 ${ }^{\text {th }}$ 1938, the Jewish inhabitants of Kittsee and Pama, Burgenland, Austria, were ejected from their homes, robbed of what money and identity papers they had and, during the night, marooned on some a small island in the Czech section of the Danube. On April 17 ${ }^{\text {th }}$, they were found by the Czech frontier guard and taken to Bratislava. That very same day they were expelled from Czecho-Slovakia [sic] and once again taken to the German border."

These opening lines are from a report by Marie Schmolka ${ }^{2}$ that documents the fate of a group of Jews from Burgenland, the easternmost Austrian federal province, who were expelled from Austria across the border into Czechoslovakia in April 1938. Her report is an example of the rapid exclusion, disenfranchisement and expulsion of the Austrian Jews and the theft of property immediately after the so-called "Anschluss" of Austria to the German Reich in March 1938.

\footnotetext{
* This work was supported by Czech Science Foundation under the project GA18-16793S "Citizens of the No Man's Land. Jewish refugees and erosion of citizenship in East-Central Europe, 1935 - 1939".

1 The Wiener Library for the Study of the Holocaust and Genocide (WL), fonds (f.) Jewish Central Information Office (JCIO), WL 3000/9/1/954, The Burgenland Jews on the Danube tug-boat. An eyewitness Report.

2 Marie Schmolka, neé Eisner (1893 - 1940), was a pioneer of Jewish social work and a leading figure in several Jewish and Zionist aid organisations in Czechoslovakia. From 1933 onwards she also assisted German and Austrian refugees as the head of the Jewish Relief Committee.
} 
Life for the Jewish population rapidly became more difficult. Within a month, the first decrees and orders aimed at excluding the Jewish population from all areas of public life and almost all professions came into force ${ }^{3}$ and impoverished large segments of the Jewish population. This Nazi policy resulted in a mass exodus of the Austrian Jewish population: At the time of the "Anschluss", around 206000 Austrians were considered Jewish according to the Nuremberg Laws. By September 1939, the number of Austrian Jews living in the territory of the former Austrian state fell rapidly to around 77000 people. ${ }^{4}$ While most Austrian Jews fled to Great Britain, followed by the United States, Palestine, Switzerland and later to Shanghai, ${ }^{5}$ for thousands of Austrian Jews Czechoslovakia became their first place of refuge. Czechoslovakia was an important place of refuge for Austrian Jewish refugees for a number of reasons: its geographical proximity made it easier to seek refuge there; Czechoslovakia was still democratic; there was a large German-speaking minority; additionally, historical connections across the relatively new border meant that many Austrians had family ties there. These connections also led to many refugees entering the country and not contacting state authorities, aid organisations or refugee committees because they were staying with relatives, making a precise estimate of the number of refugees difficult. Nevertheless, based on Austrian and Czechoslovak documentation, it can be assumed that more than 5000 Austrian Jews fled to Czechoslovakia between March 1938 and March 1939 or were expelled from Austria and sent there. ${ }^{6}$

A large number of the Jewish refugees who fled from Austria to Czechoslovakia in 1938 were unable to escape again after Czechoslovakia was occupied by Nazi Germany in March 1939. From autumn 1941 onwards, about 2300 people who had had had their permanent residence in Austria before 1938 were deported from what had become the Protectorate of Bohemia and Moravia. ${ }^{7}$

This article focuses on how the geo-political changes following the "Anschluss" and later developments, such as the Munich Agreement in September 1938 and the occupation of Czechoslovakia by Nazi Germany in March 1939, affected the lives and prospects of Austrian Jews in Austria, and later as refugees in Czechoslovakia. It also addresses how the evolving situation saw the possibilities of escape from Austria changed from seeking refuge to expulsion, smuggling and trafficking as well as the deportation of Austrian refugees by the Czechoslovak authorities along the border.

3 On first "juridifications" of the exclusion of the Jewish population after the "Anschluss" see: ARNBERGER, Heinz - GARSCHA, Winfried R. - MITTERRUTZNER, Christa (eds.) „Anschluß“ 1938. Eine Dokumentation. Wein : DÖW, 1988, p. 439.

4 MOSER, Johnny. Demographie der jüdischen Bevölkerung Österreichs - 1938 - 1945. Wien : DÖW, 1999, p. 38.

5 Ibid, p. 66.

6 See e.g.: MOSER 1999a, p. 66; Národní archiv České republiky (NA), f. Presidium ministerstva vnitra (PMV), 1936 - 1940, box (b.) 225-1187-2, number (no.) X/R/3/2, Monthly statistics on the number of Austrian emigrants in the Republic of Czechoslovakia by the regional authorities in Prague.

7 See: Victim Database of the Documentation Centre of Austrian Resistance (DÖW). Available online: http://www.doew.at/english. 
The article looks only peripherally at the domestic Czechoslovak reaction and Czechoslovak policies towards the Austrian Jews after the "Anschluss", as already outlined by the historians Kateřina Čapková and Michal Frankl. ${ }^{8}$ Instead it focuses on the fate of Austrian refugees in the border region after the "Anschluss" of March 1938, the expulsion of Jews from Burgenland in April 1938 and smuggling and trafficking activities as well the expulsions from Czechoslovakia in the summer of 1938. Czechoslovakia quickly changed from being a place that Jewish refugees from Austria (and other countries) could escape to, into a point of transit on their route to countries such as Great Britain, Belgium and France. ${ }^{9}$

The large number of refugees who found themselves unable to continue their journey out of Czechoslovakia and who were later murdered in the Holocaust has also led to the fact that Czechoslovakia has not been seen to be of primary interest in research relating to exiles. By emphasizing the experience of "ordinary" refugees whose experiences exemplify the broader experiences of refugees at this time, the article includes the biographies of individual Austrian refugees, the reconstruction of which has only been made possible by transnational research.

\section{Implementing Transnational and Spatial Approaches}

Research investigating the emigration as refugees and the exile of Austrian Jews after 1938 in general can be found as early as the $1960 \mathrm{~s},{ }^{10}$ a comprehensive study of Austrian refugees in Czechoslovakia, however, is still lacking. This can be seen most obviously by looking at the published studies that have dealt with refugees from the German Reich: The seven volumes of the series Austrians in Exile (Österreicher im Exil) published by the Documentation Centre of the Austrian Resistance (Dokumentationsarchiv des Österreichischen Widerstandes, DÖW) contain several documents relating to refugees in Czechoslovakia and referring to the importance of Czechoslovakia as a country of exile for Austrian refugees. Nevertheless, a volume dedicated to Czechoslovakia (or any other neighbouring country of Austria) is yet to be published. ${ }^{11}$ The series Die Verfolgung und Ermor-

8 FRANKL, Michal. Prejudiced Asylum: Czechoslovak Refugee Policy, 1918 - 1960. In Journal of Contemporary History, 2014, vol. 49, no. 3, pp. 537-555; ČAPKOVÁ, Kateřina - FRANKL, Michal. Unsichere Zuflucht. Die Tschechoslowakei und ihre Flüchtlinge aus NS-Deutschland und Österreich 1933 1938. Wein : Böhlau, 2012 [Czech version: ČAPKOVÁ, Kateřina - FRANKL, Michal. Nejisté útočiště: Československo a uprchlíci před nacismem 1933 - 1938. Praha : Paseka, 2008].

9 After the occupation of Czechoslovakia and the declaration of the independent state of Slovakia in March 1939, Slovakia became the most important place of refuge for Austrian Jews in the former Czechoslovakia with approx. 2200 refugees.

10 For an overview of the research on Austrian Jews in exile see e.g.: ADUNKA, Evelyn et al. Exilforschung: Österreich Leistungen, Defizite \& Perspektiven. Wien : Mandelbaum Verlag, 2018; WEINZIERL, Erika. Die österreichische Geschichtsforschung und die Exilforschung. In ADUNKA, Evelyn - ROESSLER, Peter (eds.) Die Rezeption des Exils. Geschichte und Perspektiven der österreichischen Exilforschung. Wien : Mandelbaum Verlag, 2003, pp. 35-45.

11 To date volumes of the series "Österreicher im Exil" have been published on France, Belgium, the United Kingdom, the USA, the Soviet Union and Spain by DÖW: WEINZIERL, Ulrich (ed.) Österreicher im Exil: Frankreich 1938 - 1945. Eine Dokumentation. Wien : Österreichischer Bundesverlag - Jugend und Volk, 1984; WEINZIERL, Ulrich (ed.) Österreicher im Exil: Belgien 1938 - 1945. Wien : Österreichischer Bundesverlag - Jugend und Volk, 1987; MUCHITSCH, Wolfgang (ed.) Österreicher im Exil: Großbritannien 1938 - 1945. Wien : Österreichischer Bundesverlag, 1992; EPPEL, Peter (ed.) Österreicher im Exil: USA 1938 - 1945. Wien : Deuticke, 1995; MCLOUGHLIN, Barry - SCHAFRANEK, Hans (eds.) Österreicher im Exil: Sowjetunion 1938 1945. Wien : Deuticke, 1999; KLOYBER, Christian - PATKA, Marcus G. (eds.) Österreicher im Exil: Mexiko 1938 -1945. Wien : Deuticke, 2002; GALANDA, Brigitte - LANDAUER, Hans - MANOSCHEK, Walter - NEUGEBAUER, 
dung der Juden durch das nationalsozialistische Deutschland 1933 - 1945 from the Institute of Contemporary History, Munich-Berlin has made substantial contributions to the research and body of literature relating to Jewish refugees from Nazi Germany to Czechoslovakia in their volume Deutsches Reich und Protektorat 1939 - 1941. ${ }^{12}$ However, there is little detail about Austrian refugees in Czechoslovakia.

One reason for this insufficient scientific research into Czechoslovakia as a destination of exile for Austrian Jews between 1938 and 1939 is that asylum and refugee destinations were long-associated with the "West", while the refugee policy of Eastern-Central European states has not been sufficiently addressed. This may be due in part to the large number of Jews who - having fled Austria - found themselves unable to continue their journey out of Czechoslovakia and were murdered in the Holocaust. Further possible explanations include a tendency by both German-language and Czechoslovak historiography to focus on political refugees or well-known artists and intellectuals. ${ }^{13}$ An examination of the fate and everyday lives of refugees and people expelled after the "Anschluss" in 1938, who were not members of the political and cultural elite, has - until more recently - often been neglected.

Research focusing on Czechoslovakia as a place of refuge for Austrian Jews after the "Anschluss" in 1938 was for a long time limited to just a few articles. ${ }^{14}$ Only more recently has the topic been addressed in more depth. ${ }^{15}$ In their book Unsichere Zuflucht, Kateřina Čapková and Michal Frankl detail the reaction of the Czechoslovak state towards refugees from Germany and Austria throughout the 1930s. They also look closely at the aid available to refugees in the country, primarily drawing on Czech archival material. ${ }^{16}$

Wolfgang - SAFRIAN, Hans (eds.) Für Spaniens Freiheit. Österreicher an der Seite der Spanischen Republik 1936 - 1939. Wien : Österreichischer Bundesverlag - Jugend und Volk, 1986.

12 LÖW, Andrea (ed.) Die Verfolgung und Ermordung der europäischen Juden durch das nationalsozialistische Deutschland 1933 - 1945. Vol. 3: Deutsches Reich und Protektorat September 1939 September 1941. Oldenburg : De Gruyter, 2012.

13 See e.g.: ALBRECHTOVÁ, Gertruda. Zur Frage der deutschen antifaschistischen Emigrationsliteratur im tschechoslowakischen Asyl. In Historica, 1964, vol. 8, no. 1, pp. 177-233; BECK, Miroslav - VESELÝ, Jiří. Exil und Asyl. Antifaschistische deutsche Literatur in der Tschechoslowakei, 1933 - 1938. Berlin : Volk und Wissen Verlag, 1981; SPIELMANN, Heinz. Kokoschka in Prag. In BECHER, Peter - HEUMOS, Peter (eds.) Drehscheibe Prag. Zur deutschen Emigration in der Tschechoslowakei 1933 - 1939. München : Oldenbourg Wissenschaftsverlag, 1992, pp. 87-96; TOMEŠ, Jan M. John Heartfield und der Künstlerverein Mánes. In BECHER - HEUMOS 1992, pp. 65-74.

14 For example, MOSER, Johnny. Československo ako ciel' úteku rakúskych Židov. In NIŽŇANSKÝ, Eduard (ed.) Židovská komunita na Slovensku. Obdobie autonómie. Porovnanie s vtedajšími udalost'ami v Rakúsku. Bratislava : Inštitút judaistiky Univerzity Komenského v Bratislave, 1999, pp. 86-88; IGGERS, Wilma A. Die Emigration der deutschen und österreichischen Juden in der Tschechoslowakei. In HOENSCH, Jörg K. - BIMAN, Stanislav - LIPTÁK, L'ubomír (eds.) Judenemanzipation - Antisemitismus - Verfolgung in Deutschland, Österreich-Ungarn, den Böhmischen Ländern und der Slowakei. Essen : Klartext, 1999, pp. 143154.

15 Recently see e.g.: The digital online edition BeGrenzte Flucht. Die österreichischen Flüchtlinge an der Grenze zur Tschechoslowakei im Krisenjahr 1938 was edited by Michal Frankl and Wolfgang Schellenbacher and funded by the Future Fonds of the Republic of Austria and published with help of new tools for digital editing by the European Holocaust Research Infrastructure (EHRI). Available online: https://begrenzteflucht.ehri-project.eu/; ČAPKOVÁ - FRANKL 2012; POLAČKOVÁ, Zuzana. Flucht in die Tschechoslowakei nach dem „Anschluss“ Österreichs 1938. In BRANDES, Detlef - IVANIČKOVÁ, Edita - PEŠEK, Jiří (eds.) Flüchtlinge und Asyl im Nachbarland. Die Tschechoslowakei und Deutschland 1933 bis 1989. Essen : Klartext, 2018, pp. 89-104.

16 ČAPKOVÁ - FRANKL 2012. 
In 2018, the online edition BeGrenzte Flucht. Die österreichischen Flüchtlinge an der Grenze zur Tschechoslowakei im Krisenjahr 1938 was published, combining archival material from Austria and the Czech Republic (and to a lesser extent Slovakia) and offers an insight into the process of seeking refuge, of expulsions and deportations along the border of Czechoslovakia and the former Austrian territory after the "Anschluss". BeGrenzte Flucht applies spatial studies and utilises geo-referencing of Czech and Austrian documents to offer fresh new perspectives on the border region as a dynamic space of interaction. Additionally, by paying close attention to aspects of space, it is possible to track the lives, escape routes and fates of "ordinary" Austrian Jewish refugees in Czechoslovakia, and not just those refugees from the political and cultural elite.

This article follows this approach and deals with the interrelated processes of flight, expulsion, smuggling and trafficking in the border region as well as the deportation of Austrian refugees by the Czechoslovak authorities across the border.

\section{The "Anschluss"}

The Nazi movement found no major support in Austria until the mid-1930s, however, the idea of an "Anschluss" to Germany of the new Austrian state that emerged from what was left of the Austro-Hungarian Empire found wide acceptance which increased due to the political and economic crises of the 1930s.

Nazi Germany continued to put pressure on the Austrian state throughout the 1930s, eventually culminating in the Berchtesgaden Agreement between Hitler and the last dictatorial chancellor of Austria, Kurt Schuschnigg, in February 1938, in which a series of measures favouring Austrian National Socialists were established. Austrian National-Socialist functionaries and their sympathisers occupied key positions in the Austrian state. Most importantly, Arthur Seyss-Inquart was appointed as the Minister of the Interior with absolute authority over the police, encouraging the Nazis to intensify their actions in Austria.

To prevent a referendum on the autonomy of Austria that was planned by the Austrian government, a series of ultimatums forced Kurt Schuschnigg to step down and the Austrian president was strong-armed into appointing Seyss-Inquart as the new chancellor of Austria. German troops crossed the border into Austria at 5.30 a. m. on $12^{\text {th }}$ March 1938. On $15^{\text {th }}$ March Hitler declared the "Anschluss" of Austria to the German Reich. Both the "Anschluss" and the Nazi regime found broad-based support from the Austrian population. ${ }^{17}$

As the "Anschluss" was happening, the first pogrom-like excesses against the Austria's Jewish population started: anti-Semites from all parts of Austrian society arrested, beat and humiliated Jews, looting their shops and forcing Jews to clean the streets and pavements with rags and brushes. ${ }^{18}$

17 BOTZ, Gerhard. Wien vom „Anschluß“ zum Krieg. Nationalsozialistische Machtübernahme und politischsoziale Umgestaltung am Beispiel der Stadt Wien 1938/39. Wien : Jugend und Volk, 1978.

18 WITEK, Hans - SAFRIAN, Hans. Und keiner war dabei. Dokumente des alltäglichen Antisemitismus in Wien 1938. Wien : Picus, 2008 s; ARNBERGER - GARSCHA - MITTERRUTZNER 1988, „Anschluß“ 1938. 
Prior to the "Anschluss", the Austrian border with Czechoslovakia had already seen the refugee movements, smuggling activities, forced deportations and illegal border crossings. Refugees fleeing the Russian Front during the First World War had been accommodated in refugee camps along the border, for example, and ad hoc deportations of "unwanted persons" had been carried out by the Austrian police during the late 1920s and early 1930s. ${ }^{19}$ Such deportations increased from 1933 onwards, especially of German, Polish or stateless Jews who attempted to flee from Germany to Austria via Czechoslovakia. If caught, they would be deported back to Czechoslovakia by the Austrian police and security authorities. ${ }^{20}$ Previously established routes were used by political activists, living in exile in Czechoslovakia, to smuggle propaganda materials after the failed "February Uprising" in 1934. The initially benevolent attitude of the Czechoslovak state towards these Socialist paramilitaries and political functionaries soon waned, something that was also reflected in the attitude of the media and politicians. ${ }^{21}$

As pointed out by Čapková and Frankl, Jewish refugees fleeing Nazi Germany in the mid-1930s were often considered to be "economic migrants", emigrating as a result of their exclusion from economic life and were not granted asylum. ${ }^{22} \mathrm{Popu}-$ list newspapers warned against alleged criminality that the refugees brought and accused them of being unwilling to integrate. ${ }^{23}$

\section{The "Anschluss" at the Austrian-Czechoslovak Border}

Immediately prior to the "Anschluss" of Austria to Nazi Germany, the Czechoslovak authorities feared a wave of refugees from Austria entering Czechoslovakia. The Czechoslovak Ministry of the Interior issued a general ban on the entry of refugees from Austria on $12^{\text {th }}$ March 1938 and ordered that the borders be closed to all Austrian citizens. ${ }^{24}$ The "Anschluss" occurred the next day.

The impact of closing the Austrian-Czechoslovak border became obvious within a matter of hours. Fearful of the impending danger presented by the "Anschluss", small groups of people attempted to cross the border into Czechoslovakia. Telephone messages to the state authorities in Brno from the local police and state finance offices documented several incidents in which Austrian refugees were refused entry and sent back. Five Austrians who tried to cross the border between Kleinhaugsdorf and Hatě (Haid) in a car were likewise refused entry and sent

19 For further information on deportations along the Lower Austrian/Czechoslovak border in the 1920s and 1930s see: SCHELLENBACHER, Wolfgang. Von Flucht und Abschiebung zur Vertreibung. Der Raum Niederösterreich als Beispiel für den Umgang mit Flüchtlingen und Abgeschobenen in Österreich zwischen 1914 und 1938. In DÖW (ed.) Fanatiker, Pflichterfüller, Widerständige. Reichsgaue Niederösterreich, Gro $\beta$ Wien. Wien : DÖW, 2016, pp. 267-284.

20 See e.g.: ČAPKOVÁ - FRANKL 2012, p. 66.

21 For a detailed description on the situation of political refugees from Austria in Czechoslovakia after 1934 see: SCHELLENBACHER, Wolfgang. From Political Activism to Disillusionment. In KOVÁCS, Éva - RÁSKY, Béla - WINDSPERGER, Marianne (eds.) S:I.M.O.N. SHOAH: INTERVENTION. METHODS. DOCUMENTATION, 2018, vol. 5 no. 2, pp. 78-94. Available online: https://doi.org/10.23777/SN0218/ SWW_WSCH01.

22 ČAPKOVÁ - FRANKL 2012, p. 187.

23 Ibid, p. 43.

24 Ibid, p. 247. 
back to Austria on the evening of $11^{\text {th }}$ March. The number of Austrians attempting to cross the Czechoslovak border continued to grow. ${ }^{25}$

In the night of the $11^{\text {th }}-12^{\text {th }}$ March, an initial peak was reached when 180 refugees on a train were sent back from the Czech border crossing at Břeclav (Lundenburg): In Vienna, hundreds of people who feared arrest or reprisals by the Nazi regime due to their ethnicity or political activities, tried to board an already overcrowded night train from Vienna to Prague, leaving at 11.15 p. m. from Vienna Ostbahnhof. SA (Sturmabteilungen) units detained the passengers, searched and harassed them and confiscated any valuables. Before the train reached the Czechoslovak border, it was again stopped within Austrian territory and once more searched. Upon finally reaching the Czechoslovak border crossing at Břeclav, the refugees were denied entry by the Czechoslovak authorities and sent back. Several survivors described their shock at these events, including George E. R. Gedye (born 1890, Great Britain), a foreign correspondent for several British and American newspapers in Austria and an opponent of the Nazi regime. He described the situation in his autobiography: "Then the head of police entered and said loudly: »I have just received instruction from the Ministry of the Interior that all Austrians are to be sent back at the border without any exception. You all have to wait here and return back with the next train.«"26

The Austrian journalist Richard Arnold Beermann, born in 1883 and working under the pseudonym Arnold Höllriegel as a journalist and travel writer, also sought to quickly escape from Austria into Czechoslovakia. He sent a telegram from the train station at the border to the Czechoslovak president Edvard Beneš that documents the despair of the refugees and their astonishment at the closed border: "( $P)$ resident dr benes prag [...] in the name of those austrian refugees being held back at the border station breclav and in my own name, I call upon humanity of the czechoslovak democracy arnold hoellriegel editor of die stunde pass name dr bermann".27

Altogether, 180 passengers on the train - 175 Austrians, two Polish and three German citizens - were denied entry and returned to Austria. ${ }^{28}$ Several of the passengers succeeded in leaving the train at the closest Austrian station and crossed the border illegally, entering Czechoslovakia via forest trails. ${ }^{29}$

Directly prior to and immediately following the "Anschluss" Austrian Jews and political opponents of the Nazi regime tried to reach Czechoslovakia via the official border crossing points. Besides the border station in Břeclav and the border

25 Moravský zemský archiv (MZA), f. B40 - Zemský úřad v Brně (ZÚB), prezidium, b. 292, no. 17886/1938, Telephone messages of the regional authority Brno on the processes at the Austrian border, $11^{\text {th }}$ March 1938.

26 From the descriptions of the English correspondent G. E. R. Gedye. Quoted from: ARNBERGER - GARSCHA - MITTERRUTZNER 1988, p. 426.

27 NA, f. PMV, 1936 - 1940, b. 225-1186-19, no. X/R/3/2, folio (fol.) 57, Telegram of Richard A. Bermann from Břeclav (Lundenburg) to president Edvard Beneš.

28 MZA, f. B40 - ZÚB, prezidium, b. 292, no. 17886/1938, Telephone messages to the regional authority Brno on the processes at the Austrian border, March $12^{\text {th }} 1938$.

29 ROSENKRANZ, Herbert. Verfolgung und Selbstbehauptung. Die Juden in Österreich 1938 - 1945. Wien : Herold, 1978, p. 31. 
between Retz and Znojmo, Bratislava was another hotspot for the movement of refugees in those first few days. According to reports in the Znaimer Wochenblatt newspaper, approximately 100 Austrian motor vehicles reached Bratislava on $12^{\text {th }}$ March $1938 .^{30}$ Since cars were being turned back at the border, a column of abandoned vehicles developed at the main border crossing points in the northern part of Lower Austria. ${ }^{31}$

\section{Forced Expulsion from Austria - The Burgenland Jews}

The rapid disenfranchisement, deprivation and expulsion of the Jewish population of Austria was carried out most rapidly in the Burgenland border region. Several municipalities with large Jewish minority populations such as Frauenkirchen, Kittsee or Lackenbach saw "wild Aryanizations" begin immediately after the "Anschluss". ${ }^{2}$

In Frauenkirchen, all 336 Jews (11.7\% of the town's population), were locked in a large building, beaten and held all day without food until the head of the Jewish community was forced to sign a document declaring that the whole Jewish community would emigrate. Jewish shops were closed and looted by the police and followers of the Nazis. Several house searches were undertaken by the Gestapo. On $26^{\text {th }}$ March and the days immediately afterwards, the first Jews from Frauenkirchen as well as from Deutschkreuz, Eisenstadt and Neusiedel am See were transported to the border crossing at Berg and expelled from Austria into Czechoslovakia. ${ }^{33}$

The Palestine Office in Prague received a detailed report on the expulsion of the Jews from Frauenkirchen: "They were transported by car to the Czechoslovak border and since the Czechoslovak border guard refused them entry, as the borders were closed to Austrian citizens, they remained outside, between the borders, until the next morning. The Austrian border guard then drove the refugees to the nearby Hungarian border, where they were also refused entry, and so this was repeated several times." ${ }^{34}$

The Czechoslovak authorities received reports that the Jews expelled from Frauenkirchen on 31 ${ }^{\text {st }}$ March 1938 had been stranded in a kind of "no-man's-land" in the Burgenland border region. They closely monitored the actions of the Gestapo and SA troops. After the group was rejected by Czechoslovakia, the Nazis tried to repeat the illegal deportation later that same day, but in smaller groups. ${ }^{35}$

30 Grenzen abgeriegelt. In Znaimer Wochenblatt, vol. 89, no. 21, March 16 ${ }^{\text {th }} 1938$, p. 2.

31 ROSENKRANZ 1978, p. 31.

32 On the persecution of the Burgenland Jews see e.g. NEUGEBAUER, Wolfgang (ed.) Widerstand und Verfolgung im Burgenland 1934 - 1945. Eine Dokumentation. Wien : DÖW, 1983; TSCHÖGL, Gert - TOBLER, Barbara - LANG, Alfred (eds.) Vertrieben. Erinnerungen burgenländischer Juden und Jüdinnen. Wien : Mandelbaum, 2004.

33 ROSENKRANZ 1978, p. 45.

34 Protocol from $8^{\text {th }}$ April 1938 and the accompanying letter from the Palestine Office in Prague to the Emigration Office of the Jewish Agency in Jerusalem. The Central Zionist Archives Jerusalem, Emigration department, S. 6/3691. Quoted in: ROSENKRANZ 1978, p. 46.

35 NA, f. PMV, 1936 - 1940, b. 225-1186-16, no. X/R/3/2, fol. 41-42, Czechoslovak Ministerium of 
For four days, the Jews expelled from Austria were repeatedly pushed back and forth. The group was provided with food by the Jewish community in Rajka (Ragendorf) and three Jews from Rusovce (Karlburg/Oroszvár). Eventually, members of the SS took their passports and expelled them across the border into Hungary. This time, most of them were able to cross the border illegally. ${ }^{36}$

In the weeks that followed, similar events took place all along the border region in the Burgenland in Deutschkreuz, Eisenstadt and Neusiedl am See. On $16^{\text {th }}$ April 1938, the Jewish inhabitants of Kittsee and Pama were forced from their homes and taken at night by boat to a small island on the Czechoslovak side of the Danube near Devín (Theben) and left there, after being robbed of all their valuables and their papers. The next morning, they were discovered by the Czechoslovak border guards and brought to Bratislava; an extended period of attempted forced expulsion and re-deportation began. On the same day they were transported by the Czechoslovak authorities to the German border and expelled. The group was again subject to an attempted deportation by the German border authorities, this time across the Hungarian border. However, they were once more returned to the territory of the former Austria. This way the group was trapped in the "noman's-land" between the borders of former Austria, Czechoslovakia and Hungary for three days in the bitter cold. Seventeen of them managed to return to Kittsee where they were forced to scrub the streets, beaten and then returned once more to the Czechoslovak border. The Jewish community in Bratislava provided the stranded with food and organised accommodation for them on the tugboat Laortis on the Danube near Rajka (Ragendorf). The 68 people, who had been expelled, including elderly people and children, would spend several months cramped together in unsanitary conditions. Still unsafe, they were attacked by the Gestapo on board and humiliated in summer $1938 .^{37}$

Marie Schmolka (born 1893, Prague) was a pioneer of Jewish social work, a leading figure in several Jewish and Zionist aid organisations in Czechoslovakia and had been the head of the Jewish Relief Committee since 1933. She investigated the matter and in a letter to the Jewish Central Information Office in Amsterdam she offered a report on the desperate situation of those forced to live on the tugboat: "It is now three months that these people, smitten with despair, refused by every country, and even grudged the stay aboard the ship - it is now three months that they are thus kept in the vague hope of salvation. [...] We have seen their unspeakable mental distress, even increased by physical torture, as they either must stay in the narrow rooms downstairs which are infested with rats and vermin, or on the upper deck where they are left to the weather's mood."138

Interior on the Expulsion of Austrian Jews over the Czechoslovak border. 36 ROSENKRANZ 1978, p. 45.

37 See e.g.: WL, coll. 608, folder 2, Report of the Jewish Telegram Agency on those stranded on the tugboat; DÖW 1983, pp. 307-330.

38 WL, f. JCIO, WL 3000/9/1/954, Correspondence with Marie Schmolka. 
It was only after prolonged pressure from the Hungarian government ${ }^{39}$ that international Jewish relief organisations succeeded in securing their emigration to Palestine and the United States in August $1938 .^{40}$

\section{Trafficking, Forgery and Illegal Deportations}

Although Czechoslovakia increased their border patrols, the long "green border" with the former Austrian territory - the natural land border between the official crossings - was difficult to control.

The increase in the number of arrests and the subsequent deportations by the Czechoslovak authorities also increased the trafficking business along the border.

Refugees soon started to use existing networks already established by smugglers in the border regions at places along the border such as Unterretzbach, Bratislava, Kaplice (Kaplitz) and along the Morava river between Marchegg and Dürnkrut. ${ }^{41}$ The Czechoslovak and German authorities as well as the Czechoslovak press soon took notice of these busy border crossing points.

On $1^{\text {st }}$ April 1938 the conservative daily newspaper Národní politika (National Politics) complained about Austrian Jews being able to cross the border along the river Morava (March) during the night "where diverse smuggling activities have always flourished". Many swam across the river using car tires to stay afloat. ${ }^{42}$

As a result, Czechoslovakia and the German Reich both increased the number of border guards along the Dunaj (Danube) and Morava. Additionally, Czechoslovakia tried to further restrict transport connections. In May 1938, the gendarmerie in Wolfsthal reported that the local electric train connection between Vienna and Bratislava (Elektrische/Viedenská električka) had been stopped before reaching the Czechoslovak border and passengers had to change onto buses. The border was then resealed using barbed wire. ${ }^{43}$

In April 1938, the Gendarmerie in Oberweiden caught a group of traffickers from Vysoká pri Morave/ Hochštetno (Hochstetten) who regularly waited for Jews from Vienna at Baumgarten a. d. March and smuggled them over the border at night. ${ }^{44}$ Since many of the smuggling routes used by traffickers were known to the German and Czechoslovak border police, crossing the border became ever more difficult.

39 FROJIMOVICS, Kinga. I Have been a Stranger in a Strange Land: The Hungarian State and Jewish Refugees in Hungary, 1933 - 1945. Jerusalem : Yad Vashem Publications, 2007.

40 NEUGEBAUER 1983, pp. 295-298; MOSER 1999b, pp. 86-88.

41 For further information on smuggling routes that existed in the early 1930s see: SCHELLENBACHER, Wolfgang. Fluchtwege und Schmuggelrouten österreichischer Flüchtlinge in die Tschechoslowakei 1934 bis 1939. In ANDERL, Gabriele - USATY, Simon (eds.) Schleppen, Schleusen, Helfen. Flucht zwischen Rettung und Ausbeutung, Wien : Mandelbaum Verlag, 2016, pp. 129-145.

42 NA, f. PMV, 1936 - 1940, b. 225-1186-17, no. X/R/3/2, fol. 97, Nedovolené zaměstnávání rakouských uprchliků. Press cutting from Národní politika, $1^{\text {st }}$ April 1938.

43 Niederösterreichisches Landesarchiv (NÖLA), Bezirkshauptmannschaft Bruck an der Leitha (BH-Bruck/ Leitha), b. 424 (XI/153) 1938.

44 NÖLA, BH-Bruck/Leitha, b. 424 (XI/153) 1938. 
Documentation of the arrests and the Gestapo's daily reports in Vienna show how the price paid to traffickers willing to help Jewish refugees into Czechoslovakia increased dramatically as the situation for the Jews in Austria became more hopeless and the borders became more tightly sealed - rising from 50-100 RM to over $1000 \mathrm{RM}$ in the late summer of $1938 .^{45}$

Next to smuggling and trafficking, the trade in falsified documents flourished as the situation for the Austrian Jews became ever harsher. The "Anschluss" marked a final phase in the ever-more restrictive refugee policy of most European countries and several countries introduced visas for Austrian citizens. ${ }^{46}$ Before long, all of Austria's neighbouring states had closed their borders to Jewish refugees. Countries like Switzerland and Czechoslovakia also sought to prevent refugees from Austria entering without too severely damaging their economic relations with Germany. Czechoslovakia refrained from introducing a blanket visa requirement for German citizens but required that holders of old Austrian passports or new passports issued within the former Austrian territory had to obtain an entry recommendation from the Czechoslovak Consulate General in Vienna. ${ }^{47}$ Only in rare cases were such entry recommendations issued to Austrian Jews. ${ }^{48}$

Therefore, a market for counterfeit entry recommendations soon flourished. On $8^{\text {th }}$ October, the Czechoslovak Consulate General lodged a complaint with the Vienna Police Department: In return for 1000 Reichsmarks, a Viennese travel company would take passports and falsify the entry recommendations of the Czechoslovak Consulate General. ${ }^{49}$

During June and July 1938, illegal deportations and expulsions by the German police and $\mathrm{SA}^{50}$ increased at the South Moravian border. Jews were brought from Vienna to the border region between Retz and Znojmo (Znaim), such as the border crossing at Unterretzbach and were then forcibly deported via dirt roads or the woods along the Dyje (Thaya) river under the cover of darkness. The illegal nature of these deportations makes it difficult to determine the exact number of people expelled in this way. The authorities in Brno reported that during this period of time, 100 refugees and expelled persons per day were caught by the Czechoslovak border officials and deported back to what had previously been Austrian - but was now German - territory. ${ }^{51}$ In common with many other cases, most of the refugees deported this way would attempt to cross the Czechoslovak border again or were expelled again by Nazi units.

45 See e.g.: DÖW, Collection Materialien über Josef KROUPA, Sign. 4040, Anklageschrift des Oberreichsanwalts beim Volksgerichtshof (VHGH) 9 J 198/39g gegen Josef Kroupa vor dem VGH. 46 Switzerland introduced a visa requirement for former Austrian citizens on $1^{\text {st }}$ April 1938, the United Kingdom introduced a visa requirement on $2^{\text {nd }}$ May 1938.

47 ČAPKOVÁ - FRANKL 2012, p. 255.

48 NA, f. PMV, 1936 - 1940, b. 225-1189-12, no. X/R/3/6, Internal remark from 30 July1938.

49 NA, f. PMV, 1936 - 1940, b. 225-1189-12, no. X/R/3/6, fol. 20, notes on the falsifications of entry recommendations.

50 Reports are conflicting about whether the units were SS, SA or border guards.

51 ČAPKOVÁ - FRANKL 2012, p. 262. 
On $23^{\text {rd }}$ July 1938 the German-language daily newspaper, the Prager Tagblatt, reported on the illegal border crossings and subsequent deportations from Czechoslovakia: "Brno. The Brno police arrested 25 refugees from Austria who arrived yesterday and went to the registration office to obtain a temporary residence permit. Four of those arrested were later released, and 21 people and two refugees who had been arrested yesterday were probably transferred to the border. [...] We receive reports from Znaim [Znojmo, W. S.] that 19 people who had been arrested these days because they crossed the border without papers were deported yesterday to the border. A young woman who came to Czechoslovakia near Schattau [Šatov, W. S.] and collapsed there was cared for by Czechoslovak gendarmes. Since she could not be transported, she was granted a temporary residence permit. ${ }^{\prime 52}$

The Central Aid Organization for Refugees in Brno (Zentralhilfsstelle für Flüchtlinge in Brünn) intervened on behalf of the refugees in Brno with the Czechoslovak Minister of the Interior Jan Černý, asking for temporary asylum by telegram..$^{53}$ The intervention was unsuccessful.

In those cases where the deportations were carried out by individual officials, new opportunities could present themselves, evidence for this has been found in in several memoirs: ${ }^{54}$

Otto Brichacek, (born 1914, Vienna) was a member of the Austrian Social Democratic Workers Party and from 1933 onwards was a member of the Austrian Communist Party. Due to his political work he was imprisoned by the Austrian dictatorial "corporative state" ("Ständestaat") ${ }^{55}$ in 1934/1935. In April 1938, he illegally crossed the border to Czechoslovakia between Retz and Znojmo with his future wife where they were caught by the Czechoslovak gendarmerie and returned to the Czechoslovak/ German border. In an interview he described what happened at the border with a Czech gendarme: "The next day, he actually brought us to the border but - I saw him do it - he gave the two young [gendarmes, W. S.] the order to go in the opposite direction. At the border he said to us: »There on the left is the way to Austria. That's where you should go. Here on the right, you pass by a forest to a bridge...", this he explained in more detail, »that's the way to Czechoslovakia, there you do not go."He turned around, left, and we went the way he described, came to Brno and then to Prague where we went to party leadership." ${ }^{\prime 56}$

52 NA, f. PMV, 1936 - 1940, b. 225-1186-16, no. X/R/3/2, fol. 143, Flüchtlinge an der Grenze abgeschoben. Press cutting from Prager Tagblatt, vol. 63, no. 71, 23 ${ }^{\text {rd }}$ July 1938.

53 NA, f. PMV, 1936 - 1940, b. 225-1186-16, no. X/R/3/2, fol. 139, Telegram of the Central Aid Organization for Refugees in Brno (Zentralhilfsstelle für Flüchtlinge in Brünn) on behalf of the refugees in Brno to the Czechoslovak Minister of the Interior Jan Černý.

54 See e.g.: BRONNER, Gerhard. Spiegel vorm Gesicht. Erinnerungen, München : Deutsche Verlags-Anstalt, 2004, p. 53.

55 On the nature of the Austrian regime between 1934 and 1938 and the terminology used, see TÁLOS, Emmerich. Das Austrofaschistische Herrschaftssystem in Österreich 1933 - 1938. Berlin - Münster - Wien : LIT Verlag, 2013; WENNINGER, Florian - DREIDEMY, Lucile (eds.) Das Dollfuß/Schuschnigg-Regime 1933 - 1938. Vermessung eines Forschungsfeldes. Wien - Köln - Weimar : Böhlau Verlag, 2013; REITER-ZATLOUKAL, Ilse ROTHLÄNDER, Christiane - SCHÖLNBERGER, Pia (eds.) Österreich 1933 - 1938. Interdisziplinäre Annäherungen an das Dollfuß-/Schuschnigg-Regime. Wien - Köln - Weimar : Böhlau Verlag, 2012; NEUGEBAUER, Wolfgang - TÁLOS, Emmerich (eds.) „Austrofaschismus”. Beiträge über Politik und Kultur 1934 - 1938. Wien : Löcker Verlag, 1988.

56 DöW, Oral History Collection, Interview no. 734, Interview with Otto Brichacek. 
After the occupation of Czechoslovakia in March 1939, he continued to seek refuge in Poland, Denmark and the United Kingdom. Like many of the political refugees from Austria, Otto Brichacek returned to Austria after the end of the war.

Such assistance from border officials was most likely an exception. Similar detainments ended in tragedy: Paul (Pavel) Kastner, born 1891, was an Austrian citizen who lived in Vienna and worked as a company associate. During the night of the $16^{\text {th }}-17^{\text {th }}$ August 1938, he attempted to illegally cross the border into Czechoslovakia close to Wolfsthal, helped by a trafficker. Detected by the Czechoslovak police near the Czechoslovak-German border on the right bank of the Danube at $12.50 \mathrm{a}$. m., Kastner ingested an unknown poison and died a few minutes later. The trafficker, Nikola Novakov, was imprisoned by the Bratislava police for ten days for crossing the state border illegally. He stated during his police interview that Pavel Kastner had paid him 100 Reichsmarks for his services. ${ }^{57}$

Mapping the escape routes as well as places where smuggling, trafficking and deportations took place along the border through the geo-referencing of archival material can lead us to a focus on the fates of the average, "ordinary" Austrian Jewish refugees in Czechoslovakia. The locations where people crossed the border would be an important factor in the further fate of the refugees. This becomes most obvious in the differences between those who found themselves in the Protectorate Bohemia and Moravia and those who ended up in Slovakia after March 1939. While almost all of the Austrian refugees were transported from the Protectorate between autumn 1941 and 1943, the fate of Austrian Jewish refugees in Slovakia could greatly differ, as shown by the fate of the Kolm family.

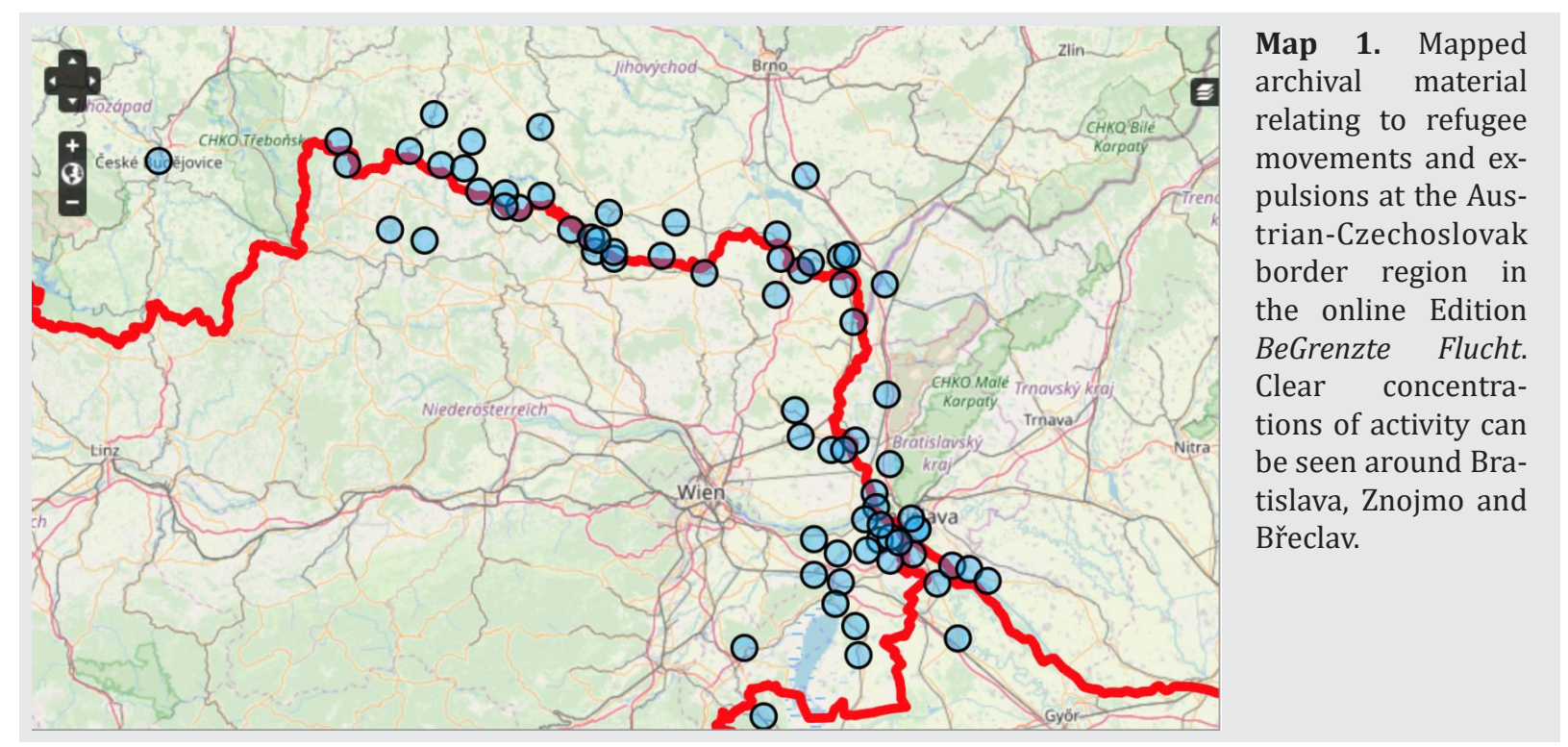

Emanuel Kolm was born in 1880 in Vienna as one of seven children to Jakob and Karoline Kohn. Both Emanuel Kohn and his brother Adolf changed their name from Kohn to Kolm due to the increasing anti-Semitism in Vienna. He worked as a mechanical engineer and had a son from his first marriage and a daughter from his 
second marriage. His second wife Sophie Kolm was born in 1886 in Svitavy (Zwittau) and worked as a pianist. Emanuel and Sofie Kolm lived in Vienna's $4^{\text {th }}$ district - a predominantly middle-class area.

After the "Anschluss" of Austria to the German Reich in 1938, their daughter escaped to the United Kingdom with a "Kindertransport", while the couple fled to Bratislava. ${ }^{58}$ In September 1944, Emanuel and Sophie Kolm were transported to Sered'. When Transports from Sered' to Auschwitz were redirected to the Terezín (Theresienstadt) Ghetto, the couple arrived there in early 1945 where they were eventually liberated. ${ }^{59}$

Emanuel died in 1951, his wife Sophie died aged 100 in 1986 in a Jewish old people's home in Vienna. ${ }^{60}$

\section{Austrian Jewish Refugees in Czechoslovakia after the Munich Agreement}

Following the signing of the Munich Agreement by Italy, France and Great Britain on $30^{\text {th }}$ September 1938, in which parts of Czechoslovakia were ceded to Nazi Germany, it became clear that Czechoslovakia was no longer a safe place of exile anymore. It became an intermediate point for further emigration to other countries. This also changed the composition of the people fleeing from Austria to Czechoslovakia: Those who emigrated immediately after the "Anschluss" were disproportionately male and aged 18-45 years. While many families had also tried to flee to Czechoslovakia prior to autumn 1938, the composition of the Austrian refugees after the Munich Agreement became much more similar to that of other countries of exile. Many countries allowed only young men with specific trades or training to immigrate. Other men were sent ahead to establish themselves, find a job and accommodation for their family who planned to join them at a later date. When emigration from the German Reich ceased completely in the autumn of 1941, the Jewish community of Vienna was predominantly female and older than average. ${ }^{61}$ By combining information contained in archives in Austria and the Czech Republic, the biographies and fates of those people who fled to Czechoslovakia from Austria, leaving their families behind to search for further opportunities for emigration, can be partially reconstructed.

In this way, Max Sternberg shared the fate of many other Austrian refugees who went to Czechoslovakia after the Munich Agreement. Most of those 2300 Austrian refugees in Czechoslovakia who had been unable to leave the country after the German occupation in March 1939 were transported from the Protectorate of Bohemia and Moravia to the Terezín Ghetto. The majority of those Austrian refugees - approximately 655 people ${ }^{62}$ - who were further deported to the ghettos, concentration camps and death camps in the East were transported from Terezín to Auschwitz.

58 Slovenský národný archív (SNA), f. Ministerstvo vnútra (MV), b. 253, Súpis Židov 1942, Bratislava. 59 DöW, no. 20.100/5998 resp. DÖW, no. 20.100/6000, Concentration Camp Association Files (KZVerbandsakten) of Emanuel Kolm and Sophie Kolm.

60 Biography of the Kohn family on Centropa. Available online: https://www.centropa.org/de/biography/ richard-kohn.

61 See Victim Databases of the DöW. Available online: http://www.doew.at/english.

62 Ibid. 
Max Sternberg was born in 1893 in Vienna, the son of Abraham and Theresie Sternberg. He worked as a salesman and married Irene Sternberg in 1922. In December 1923 their daughter was born. Prior to the "Anschluss" in 1938, the family had lived in a small council apartment in Brigittenau - a predominantly working-class area of Vienna. Their $34 \mathrm{~m}^{2}$ apartment consisted of a room, a kitchen and an anteroom. ${ }^{63}$

The expulsion of Jewish tenants, which began in Vienna in June $1938,^{64}$ started with the termination of their tenancy agreements for properties owned by the City of Vienna, ${ }^{65}$ this played an important role in the deprivation and expropriation of the Jewish population after the "Anschluss" in 1938. By the end of 1938, almost all Jewish tenants had been expelled from the city-owned buildings and resettled into buildings that already had a high Jewish population, leading to a "ghettoization" of the Jewish population of Vienna along the Danube Canal. ${ }^{66}$

The Sternberg family was also forced to leave their apartment after their tenancy was terminated by the City of Vienna in June 1938. The family was given until $31^{\text {st }}$ July to vacate the property and were forced to turn the property over on $1^{\text {st }}$ August. ${ }^{67}$

As was the case for many male refugees from the German Reich, Max Sternberg emigrated alone to find accommodation, a job and further opportunities for the emigration of his family. As his brother Ludwig had been able to emigrate to Brno and then had gone on to Singapore, he also went to Brno. Max Sternberg crossed the border into Czechoslovakia at the Suchdol nad Lužnicí (Suchenthal) border crossing at the turn of the year 1938/1939, as did his other brother Ignatz and his sister-in-law Herta. He was supported by his brother in Singapore who had left money behind and tried in vain to find a way to emigrate to Italy and to Singapore. ${ }^{68}$

His wife and daughter avoided being transported in one of the mass transports leaving Vienna in May 1942 by hiding in a coal cellar on the outskirts of Vienna where they lived for three years in terrible conditions. In January 1945, Irene Sternberg who suffered from bronchial asthma in the cold cellar, died in hiding. Their daughter survived the war. ${ }^{69}$

In July 1943, Max Sternberg was transported to the Terezín (Theresienstadt) ghetto, quite a bit later than the other Austrian refugees in Czechoslovakia due to the help of his brother Ignatz, who worked for the Jewish Community in Prague. Two months

63 DÖW database (DB), f. Kündigungsakten, Kündigungsakt Max Sternberg, 28. 6. 1938.

64 The eviction of Jewish tenants from properties owned by the city of Vienna therefore started before the law was passed excluding Jewish tenants from protection in the whole of the German Reich. See.: RAGGAM-BLESCH, Michaela. „Sammelwohnungen“ für Jüdinnen und Juden als Zwischenstation vor der Deportation, Wien 1938 1942. In SCHINDLER, Christine (ed.) Forschungen zu Vertreibung und Holocaust. Wien : DÖW, 2018, pp. 81-100. 65 BOTZ, Gerhard. Wohnungspolitik und Judendeportation in Wien 1938 bis 1945. Zur Funktion des Antisemitismus als Ersatz nationalsozialistischer Sozialpolitik. Wien : Geyer-Edition, 1975.

66 See in more detail: EXENBERGER, Herbert - KOSS, Johann - UNGAR-KLEIN, Brigitta. Kündigungsgrund Nichtarier, Die Vertreibung jüdischer Mieter aus den Wiener Gemeindebauten in den Jahren 1938 - 1939. Wien : Picus Verlag, 1996.

67 DÖW DB, f. Kündigungsakten, Kündigungsakt Max Sternberg, 28. 6. 1938.

68 NA, f. Policejní ředitelství v Praze (PRP) 1941 - 1950, b. 450, no. S 5996/6, S, Sternberg Max.

69 DöW, no. 20.000/K149, Opferfürsorgeakt of the daughter of Max and Irene Sternberg. 
later he was transported to Auschwitz and housed in the "Theresienstadt Family Camp". Max Sternberg was murdered in Auschwitz.

As the exclusion and disenfranchisement of the Jewish population in Nazi Germany increased, Austrians continued to attempt to flee to Czechoslovakia up until the beginning of 1939. After the occupation of Czechoslovakia in March 1939, those Jewish refugees from Austria who were already in Czechoslovakia once more had to seek new countries to emigrate to. Many found exile in the UK, France, Belgium and the United States. Many refugees managed to cross the border into Slovakia. The outbreak of the war essentially ended any opportunity for further emigration from Czechoslovakia for most of the refugees.

From $16^{\text {th }}$ October 1941 onwards, the first mass transportations left from the Protectorate of Bohemia and Moravia for the Litzmannstadt Ghetto ( Łódź). After 24 ${ }^{\text {th }}$ November 1941, mass transportations followed to the Terezín Ghetto (Theresienstadt). The Austrian and Czech Shoah victim database shows the extent to which the Austrian Jews who fled to Czechoslovakia or were expelled from Austria over the Czechoslovak borders after the "Anschluss" were further persecuted: From the autumn of 1941 onwards, approximately 2300 Austrian Jews were transported from the Protectorate of Bohemia and Moravia to the ghettos, concentration and extermination camps..$^{70}$ As was the case for Max Sternberg, most did not survive the Holocaust.

Approximately 190 Austrian refugees were transported from Prague to the Litzmannstadt Ghetto in the autumn of 1941, forming the second largest group of Holocaust victims transported from the Protectorate Bohemia and Moravia. ${ }^{71}$ The fate of the Austrian Jewish refugee Karl Meisel, who was transported from Prague to Litzmannstadt, is typical of the many refugees who tried on multiple occasions to cross the border into Czechoslovakia.

Karl Meisel was a Jewish Austrian citizen born in Přerov (Prerau) in 1891. He studied law in Vienna where he would later practice, living in the city centre, at Petersplatz $4 .^{72}$

Jewish lawyers and judges were banned from practicing their profession on $31^{\text {st }}$ March 1938, just weeks after the "Anschluss". In September 1938, Karl Meisel attempted to illegally cross the border to Bratislava, but was caught by the border police, detained for 48 hours, fined 50 crowns and subsequently deported. His second attempt to illegally cross the border into Czechoslovakia on $5^{\text {th }}$ February 1939 was successful. He went to Prague, where he worked as a cook. He continued his efforts to obtain a visa for the United States, but this was made impossible by the outbreak of the war. In April 1941, Karl Meisel tried instead to emigrate to Shanghai, but this would also be in vain. ${ }^{73}$ On $3^{\text {rd }}$ November 1941 he was transported from Prague to the Litzmannstadt Ghetto. Karel Meisel was murdered in the Holocaust. ${ }^{74}$

70 Victim databases of the DÖW. Available online: http://www.doew.at/english.

71 Ibid. Many thanks to Gerhard Ungar for making the data available to the author.

72 Ibid.

73 NA, f. PRP 1941 - 1950, b. 334, no. 1895/1, M, Meisel Karel.

74 Victim databases of the Terezín Initiative Institute, Prague. Available online: https://www.holocaust.cz/ databaze-obeti/obet/145729-karel-meisel/. 


\section{Conclusion}

The racial definition established by the Nuremberg Laws meant that 206000 Austrians were considered by the Nazis to be Jewish. Approximately 135000 people managed to flee between the "Anschluss" in March 1938 and the beginning of mass deportations from Vienna in 1941. Between March 1938 and March 1939, more than 5000 refugees crossed the border into Czechoslovakia or were expelled from the former Austrian territory.

This article has shown how the closing of the border between Czechoslovakia and what was previously the Austria border led to an increase in illegal border crossings, smuggling and trafficking activities in a border region that was not unfamiliar with smuggling activities prior to 1938.

As the situation, firstly in Austria and then in Czechoslovakia changed, so too did the nature of the refuge for those Austrian refugees who had fled. No longer safe, they were forced to attempt further emigration to other countries in the face of antirefugee sentiment throughout Europe on the brink of war. From the autumn of 1941 onwards, around 2300 of the Austrian refugees in Czechoslovakia who had been unable to leave the country were deported from what had now become the Protectorate of Bohemia and Moravia to the ghettos and extermination camps in the East.

Some of the incidents relating to Austrian Jews seeking refuge and those expelled from Austria to Czechoslovakia between 1938 and 1939 are better known to researchers than others and by incorporating transnational archival research, new perspectives and insights into the events can be achieved. This article has drawn on the work of projects that have linked Austrian and Czech (as well as Slovak) archival materials over recent years and have allowed the application of geo-referencing and a more nuanced spatial analysis. This has made both the escape routes and the places of expulsion more visible, along with the fate of those Austrian refugees in Czechoslovakia who were not part of the established political and cultural elite.

Cituj:

SCHELLENBACHER, Wolfgang. Sealed Borders, Trafficking and Deportation - Austrian Refugees in the Czechoslovak Border Region after the "Anschluss". In Forum Historiae, 2019, roč. 13, č. 1, s. 75-91. ISSN 1337-6861. DOI: https://doi.org/10.31577/forhist.2019.13.1.6

$\cdots$

Mag. phil. Wolfgang Schellenbacher

Masarykův ústav a Archiv AV ČR, v. v. i.

Gabčíkova 2362/10

Praha 8

18200

Česká republika

schellenbacher@mua.cas.cz 